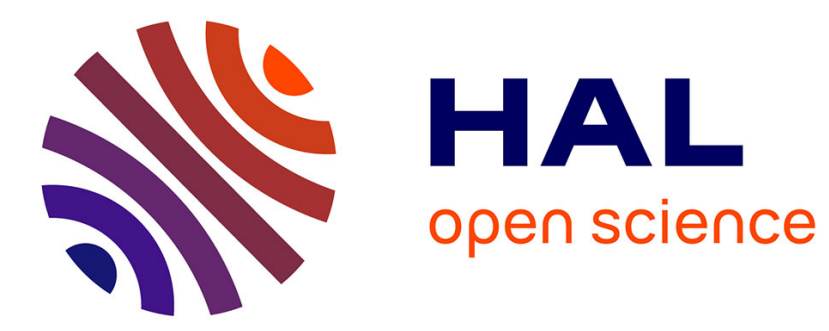

\title{
History of allergic diseases and lung cancer risk
}

Mariam El-Zein, Marie-Élise Parent, Jack Siemiatycki, Marie-Claude Rousseau

\section{To cite this version:}

Mariam El-Zein, Marie-Élise Parent, Jack Siemiatycki, Marie-Claude Rousseau. History of allergic diseases and lung cancer risk. Annals of Allergy, Asthma and Immunology, 2014, 112 (3), pp.230-236. 10.1016/j.anai.2013.12.021 . hal-01199076

\section{HAL Id: hal-01199076 https://hal.science/hal-01199076}

Submitted on 14 Sep 2015

HAL is a multi-disciplinary open access archive for the deposit and dissemination of scientific research documents, whether they are published or not. The documents may come from teaching and research institutions in France or abroad, or from public or private research centers.
L'archive ouverte pluridisciplinaire HAL, est destinée au dépôt et à la diffusion de documents scientifiques de niveau recherche, publiés ou non, émanant des établissements d'enseignement et de recherche français ou étrangers, des laboratoires publics ou privés.

\section{(ㄷ)(1)}

Distributed under a Creative Commons Attribution| 4.0 International License 


\section{History of allergic diseases and lung cancer risk}

Mariam El-Zein, PhDs,

Marie-Elise Parent, $\mathrm{PhD} \pm$ 土.

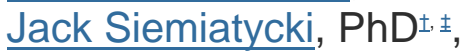

Marie-Claude Rousseau, $\mathrm{PhD}$

doi:10.1016/i.anai.2013.12.021

\section{Abstract}

\section{Background}

The exact nature and direction of the association between a history of allergic diseases and lung cancer risk remain controversial.

\section{Objective}

To examine the association between self-reported history of allergic diseases and lung cancer using data from a population-based case-control study conducted in the Montreal metropolitan area (1996-2002).

\section{Methods}

The study is based on interview data collected from 1,169 incident lung cancer cases and 1,486 controls. Separate logistic regression models were used to estimate the relative risk of lung cancer, using odds ratios (ORs) and $95 \%$ confidence intervals (Cls), in subjects with vs without asthma, eczema, or hay fever after adjustment for several sociodemographic and lifestyle factors, including smoking.

\section{Results}

For asthma, the OR was $0.90(95 \% \mathrm{Cl} 0.65-1.24)$, which decreased to 0.76 (95\% $\mathrm{Cl} 0.54-1.08)$ for subjects whose onset was more than 2 years before lung cancer diagnosis or interview and then to $0.64(95 \% \mathrm{Cl} 0.44-0.93)$ when restricted to subjects who reported using medication for their asthma. For eczema, the point estimate was $0.73(95 \% \mathrm{Cl} 0.48-1.12)$, which decreased to $0.63(95 \% \mathrm{Cl} 0.38-1.07)$ when considering eczema only in those who reported 
medication use. Hay fever showed the strongest inverse association with lung cancer (OR 0.37, 95\% Cl 0.24-0.59).

\section{Conclusion}

All 3 allergic diseases examined were inversely associated with lung cancer, although the strength of the protective effect varied. History of allergic diseases seems to have a protective role in lung cancer incidence, after consideration of potential confounders, including lifetime smoking history.

\section{Introduction}

The nature and direction of the association between a history of allergic diseases and the incidence of lung cancer have varied, depending on the type of allergic disease examined. Most evidence is suggestive of an increased risk of lung

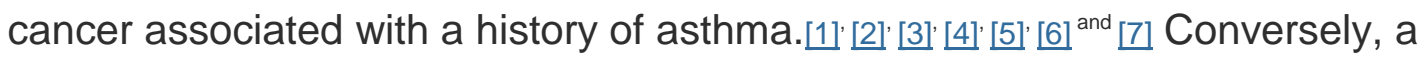
decreased risk of lung cancer associated with a history of eczema[8] ${ }^{\text {and }}[9]$ or of hay fever[10] [11] [12] [13] [14] [15] and [16] has been observed. Conflicting results across allergic diseases have provided support for 2 different hypotheses. The antigenic hypothesis proposes that immune-stimulating conditions, such as allergies, increase cancer risk through a mechanism of chronic stimulation of cells that results in the occurrence of random mutations in actively dividing cells. [8] [17] [18] ${ }^{\text {and }}[19]$ In contrast, the immune surveillance hypothesis is in line with a protective effect of allergic diseases against cancer occurrence from an enhanced immune system that can detect and destroy neoplastic cells. [8] [111] [20] ${ }^{\text {and }}[21]$

The authors took advantage of their large Canadian population-based casecontrol study to examine the association between a history of allergic diseases (asthma, eczema, and hay fever) and the risk of overall and histologically subtypes of lung cancer using a common study base and methodology. Few studies have considered all 3 allergic diseases simultaneously in the same study population. [10] [13] [2] [22] Moreover, methodologic limitations may have influenced observed associations, including restricted statistical power owing to the small number of incident lung cancer cases, exposure defined as atopy-related diseases rather than specific types of allergic diseases, and possible residual confounding by smoking, $\underline{22}$ in addition to a very low prevalence of specific types 
of allergic diseases. [10] ${ }^{\text {and }}[13]$ Also, none of these studies has reported on the temporal relation between these diseases and the incidence of lung cancer. In the present study, the authors estimated the magnitude of effect for each allergic disease, taking into account several potential confounders, including lifetime smoking history. They also explored the effect of latency exclusions on risk estimates and the relation between each allergic disease and lung cancer according to the interval from age at onset of a specific allergic disease to cancer.

\section{Methods}

\section{Selection of Cases}

A detailed description of the design, study population, and data collection methods of this population-based study, the Montreal Lung Cancer Case-Control study, is provided elsewhere. [23]' [24]' [25]' [26] ${ }^{\text {and }}$ [27] Briefly, eligible cases were men and women 35 to 75 years old residing in Greater Montreal who had been diagnosed with lung cancer. Newly diagnosed cases were ascertained from 18 hospitals in the metropolitan Montreal region, providing almost complete ( 98\%) coverage of lung cancer diagnoses in the area. Potential cases were identified through active monitoring of hospital pathologic reports and consisted of histologically confirmed primary lung cancer cases diagnosed from January 1996 through December 1997. The classification provided by the International Agency for Research on Cancer was used to code histologic subtypes of lung cancer. ${ }^{28}$ In total, 1,434 cases were invited to participate in the study and 1,203 cases $(84 \%)$ accepted.

\section{Selection of Controls}

Controls were randomly selected from the general population using electoral lists in the Province of Quebec. These lists, including the names and addresses of practically all Canadian citizens residing in Quebec, were maintained by active enumeration of households until 1994 and have been continually updated since then. Controls were matched by frequency to cases according to age group $( \pm 5$ years), sex, and broad residential area. Eligibility criteria included being a Canadian citizen, being a resident of Greater Montreal, and having no history of lung cancer. Of 2,182 population controls invited, 1,513 (70\%) participated. 
Ethics approval was obtained from all collaborating institutions, and subjects provided written informed consent.

\section{Data Collection}

Personal interviews with subjects or proxy respondents, if subjects were deceased or too ill to respond, were conducted by a team of trained interviewers. Detailed questions were asked about a wide range of factors, including sociodemographic characteristics; lifestyle habits such as diet and cigarette smoking; lifetime occupational history; and history of 11 selected medical conditions among which were asthma, allergic eczema (henceforth referred to as eczema), and hay fever.

Information about a history of allergic diseases was self-reported, ascertained through questions on whether respondents ever had asthma, eczema, or hay fever. For each positive answer, the age at onset and medication use were recorded with the type or name of medication.

Subjects who had smoked at least 100 cigarettes in their lifetime were classified as "ever-smokers." $A$ " "former smoker" was defined as someone who had quit smoking at least 2 years before recruitment. Cigarette-years were estimated as the average number of cigarettes smoked per day multiplied by the duration of smoking in years. A comprehensive smoking index (CSI), which embodies age at starting and quitting and the amount smoked, was found to provide a good fit to the data while maintaining a parsimonious representation of lifetime smoking history, in contrast to multivariable modeling of separate effects of several dimensions of smoking. $\cdot \frac{30}{}$

\section{Statistical Analyses}

The present analyses were restricted to subjects who completed the interview section on self-reported allergic diseases: 1,486 controls (98\% of participating controls) and 1,169 patients with lung cancer (97\% of participating cases).

Analyses were conducted separately for asthma, eczema, and hay fever using 2 "exposure" indicators: whether the subject reported previous occurrence of the disease, and whether the subject reported the occurrence and the associated medication use. The $\varphi$ coefficient $\left(r_{\varphi}\right)$, a measurement of association for 2 binary variables, [31] ${ }^{\text {and }}[32]$ was used to investigate the correlation between each pair of allergic diseases. In addition, the reporting of these 3 allergic diseases was 
integrated into a single composite variable to assess their independent and joint effects.

All odds ratios (ORs) and 95\% confidence intervals (Cls) were estimated using multivariate logistic regression models. Analyses were conducted for all lung cancers combined and for individual histologic subtypes. Separate models were performed for each type of allergic disease, for various combinations of these diseases, and in various strata of the population. All ORs were adjusted for the following covariates: reference age (age at lung cancer diagnosis for cases or age at interview for controls; continuous), sex (except in sex-specific analyses), educational level (elementary, secondary, or postsecondary), respondent status (self or proxy), ethnocultural origin (French origin, English origin, or other), fruit and vegetable consumption (tertiles based on the distribution among all study subjects), and smoking represented by the CSI (continuous). The latter was used to improve adjustment for smoking and thus minimize residual confounding. Several occupational lung carcinogens (chrysotile asbestos, crystalline silica, soot from any source, diesel engine emissions, and benzo- $\alpha$-pyrene), $\underline{33}$ found to be associated with lung cancer risk in this dataset, ${ }^{34}$ were initially evaluated as potential confounders. Their inclusion in the models did not materially change the risk estimates and thus they were not retained.

To explore whether early manifestations or symptoms of lung cancer could have been misreported as recent asthma, the association between asthma and lung cancer was estimated under a range of latency exclusion periods up to 10 years. That is, subjects who had reported an asthma occurrence within 1 to 10 years of the reference age were sequentially excluded from the analysis. Similar analyses were carried out for eczema and hay fever, but to define pertinent intervals from age at onset of the specific allergic disease to the reference age.

Subgroup analyses of the association between allergic diseases and lung cancer were conducted according to age at onset of an allergic disease ( $<20$ vs $\geq 20$ years) and interval from age at disease onset to the reference age. Appropriate cutoffs for "interval" categories were established based on results obtained from the "latency exclusion" analyses.

Models stratified by smoking were carried out. Subjects were classified into 2 strata based on the distribution of the continuous covariate CSI among all smokers in the study. The "never/lighter smokers" stratum included subjects who had never smoked (CSI 0) and lighter smokers (quartile 1 of the CSI distribution), 
whereas the "heavier smokers" stratum included subjects in quartiles 2 to 4 of the CSI distribution. The authors previously reported that not only were cases more likely to be in the higher CSI smoking quartiles than controls, but even within quartiles, they had higher average cigarette-years accumulated and former smokers had ceased more recently than controls. ${ }^{\frac{35}{5}}$ The interaction between CSI (2 strata) and each allergic disease (binary) was also evaluated.

When the values for certain covariates were missing, such as for educational level $(2.2 \%)$ and CSI (1.4\%), median values were imputed based on the distribution according to age, sex, and case vs control status. For missing information on fruit and vegetable consumption (3.5\%), median values were imputed based on the distribution of these same variables and ever smoking. All statistical analyses were performed using SPSS 17.0 (SPSS, Inc, Chicago, Illinois).

\section{Results}

Sex-specific sociodemographic and lifestyle characteristics of cases and controls are listed in Table 1. Cases were more likely than controls to have had a proxy respond on their behalf, to have a lower educational level, to be of French origin, to have consumed fruits and vegetables less often, and to have been heavier smokers.

Table 1.

Characteristics of the study population, separately for men and women, Montreal Lung Cancer Case-Control study, 1996 to 2002

Men

\begin{tabular}{|c|c|c|c|c|}
\hline \multirow[b]{2}{*}{ Characteristic } & & \\
\hline & $\begin{array}{l}\text { Cases } \\
(n=711)\end{array}$ & $\begin{array}{l}\text { Controls } \\
(\mathrm{n}=880)\end{array}$ & $\begin{array}{l}\text { Cases } \\
(n=458)\end{array}$ & $\begin{array}{l}\text { Controls } \\
(n=606)\end{array}$ \\
\hline Age $(y)$, mean (SD) & $64.1(7.9)$ & $65.0(7.6)$ & $61.5(9.3)$ & $61.7(9.3)$ \\
\hline Proxy respondent, n (\%) & $276(38.8)$ & $84(9.5)$ & $156(34.1)$ & $28(4.6)$ \\
\hline \multicolumn{5}{|l|}{ Education, n (\%) } \\
\hline Elementary & $332(46.7)$ & $308(35.0)$ & $165(36.0)$ & $158(26.1)$ \\
\hline Secondary & $287(10.4)$ & $368(41.8)$ & $238(52.0)$ & $268(44.2)$ \\
\hline Postsecondary & $92(12.9)$ & $204(23.2)$ & $55(12.0)$ & $180(29.7)$ \\
\hline \multicolumn{5}{|l|}{ Ethnocultural origin, $\mathrm{n}(\%)$} \\
\hline French origin & $546(76.8)$ & $565(64.2)$ & $360(78.6)$ & $417(68.8)$ \\
\hline English origin & $34(4.8)$ & $56(6.4)$ & $43(9.4)$ & $26(4.3)$ \\
\hline Other & $131(18.4)$ & $259(29.4)$ & $55(12.0)$ & $163(26.9)$ \\
\hline
\end{tabular}

Women 


\begin{tabular}{|c|c|c|c|c|}
\hline \multirow[b]{2}{*}{ Characteristic } & \multicolumn{2}{|l|}{ Men } & \multicolumn{2}{|l|}{ Women } \\
\hline & $\begin{array}{l}\text { Cases } \\
(n=711)\end{array}$ & $\begin{array}{l}\text { Controls } \\
(\mathrm{n}=880)\end{array}$ & $\begin{array}{l}\text { Cases } \\
(n=458)\end{array}$ & $\begin{array}{l}\text { Controls } \\
(n=606)\end{array}$ \\
\hline Ever smoked, n (\%) & $693(97.5)$ & $723(82.2)$ & $426(93.0)$ & $300(49.5)$ \\
\hline $\begin{array}{l}\text { Time since } \\
\text { quitting, }{ }^{\text {a }} \text { mean (SD) }\end{array}$ & $12.0(8.5)$ & $18.7(11.1)$ & $9.5(8.3)$ & $15.6(11.3)$ \\
\hline $\begin{array}{l}\text { Cigarette-years, }{ }^{\text {and }} \text { mean } \\
\text { (SD) }\end{array}$ & $\begin{array}{l}1,513.9 \\
(838.7)\end{array}$ & $\begin{array}{l}988.0 \\
(756.5)\end{array}$ & $\begin{array}{l}1,059.9 \\
(542.2)\end{array}$ & $\begin{array}{l}591.9 \\
(483.0)\end{array}$ \\
\hline \multicolumn{5}{|l|}{$\begin{array}{l}\text { Comprehensive smoking } \\
\text { index, }, n(\%)\end{array}$} \\
\hline Quartile 1 & $63(9.1)$ & $296(40.9)$ & $32(7.5)$ & $145(48.0)$ \\
\hline Quartile 2 & $132(19.0)$ & $187(25.9)$ & $131(30.7)$ & $87(28.8)$ \\
\hline Quartile 3 & $192(27.7)$ & $122(16.9)$ & $172(40.3)$ & $51(16.9)$ \\
\hline Quartile 4 & $306(44.2)$ & $118(16.3)$ & $92(21.5)$ & $19(6.3)$ \\
\hline $\begin{array}{l}\text { Fruits and vegetables/wk, } \\
\text { mean (SD) }\end{array}$ & $28.9(18.8)$ & $38.3(20.3)$ & $26.3(15.3)$ & $39.2(15.4)$ \\
\hline \multicolumn{5}{|l|}{ a } \\
\hline \multicolumn{5}{|l|}{ In former smokers. } \\
\hline \multicolumn{5}{|l|}{ b } \\
\hline \multicolumn{5}{|c|}{ In ever-smokers based on 20 cigarettes per packet. } \\
\hline
\end{tabular}

Table 2 presents, separately for men and women, the prevalence of each allergic disease. All 3 diseases were more frequently reported by women than by men. In controls, the lifetime prevalences of these diseases were $6.0 \%$ for eczema, $8.9 \%$ for hay fever, and $9.4 \%$ for asthma. Roughly two thirds of subjects who reported eczema and hay fever also reported having used medication to treat the disease, whereas close to $90 \%$ of subjects with asthma reported medication use. There were weak correlations between asthma and eczema $\left(r_{\varphi}=0.10, P<.001\right)$, between asthma and hay fever $\left(r_{\varphi}=0.13, P<.001\right)$, and between eczema and hay fever $\left(r_{\varphi=0} 0.05, P \leq .01\right)$.

Table 2.

Prevalence of allergic diseases and associated medication use, separately for men and women, Montreal Lung Cancer Case-Control study, 1996 to 2002

Men

\begin{tabular}{ll}
\hline Cases & Controls \\
$(n=711)$ & $(n=880)$
\end{tabular}

Women

\begin{tabular}{ll}
\hline Cases & Controls \\
$(n=458)$ & $(n=606)$
\end{tabular}


Men

\section{Cases}

$(\mathrm{n}=711)$

Asthma

No

Yes

Medication

use

Eczema

No

Yes

Medication

use

Hay fever

No

Yes

Medication

use
646 (90.9)

65 (9.1)

54 (7.6)

687 (96.6)

24 (3.4)

11 (1.5)

687 (96.6)

24 (3.4)

13 (1.8)
Controls

$(\mathrm{n}=880)$

814 (92.5)

66 (7.5)

$56(6.4)$

854 (97.0)

26 (3.0)

20 (2.3)

823 (93.5)

57 (6.5)

39 (4.4)

Women

\begin{tabular}{ll}
\hline Cases & Controls \\
$(n=458)$ & $(n=606)$
\end{tabular}

395 (86.2)

532 (87.8)

63 (13.8)

74 (12.2)

54 (11.8)

70 (11.6)

428 (93.4)

543 (89.6)

$30(6.6)$

63 (10.4)

19 (4.1)

$41(6.8)$

Figure 1 illustrates, for each allergic disease, the variability in ORs when excluding subjects with varying latencies from 1 year to 10 years. For all allergic diseases, the point estimates remained stable, except for a slight change in OR for asthma depending on whether latency longer than 2 years was implemented. The ORs for asthma ranged from 0.90 (95\% Cl 0.65-1.24) for no latency exclusion to $0.85(95 \% \mathrm{Cl} 0.61-1.20)$ for a latency period of 1 year and to 0.76 (95\% Cl $0.54-1.08)$ for a latency period of 2 years.

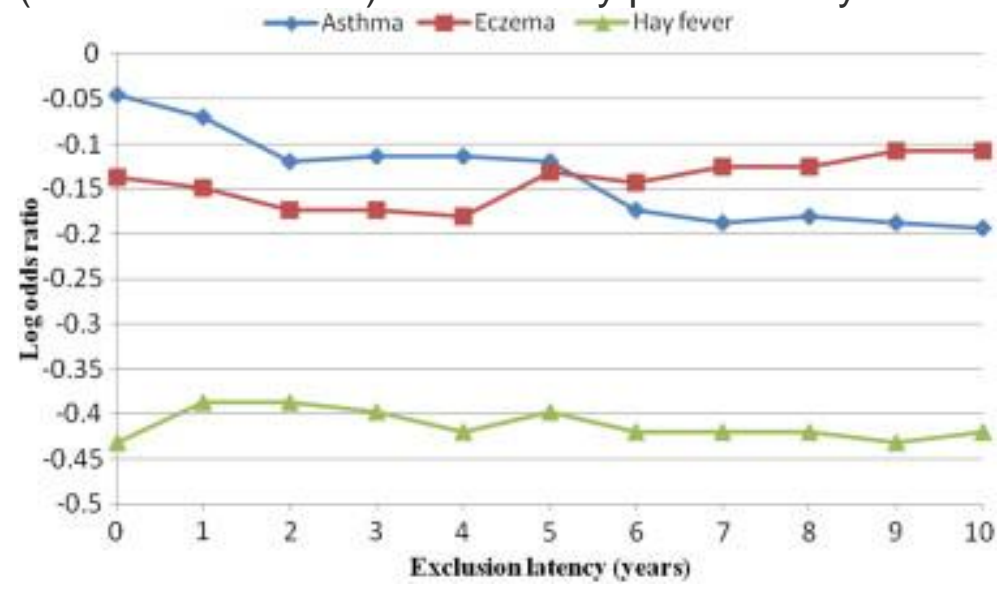

Figure 1.

Associations between previous allergic diseases and lung cancer by years of latency exclusion. Models were adjusted for age, sex, education, respondent status, 
ethnocultural origin, fruit and vegetable consumption, and smoking (represented by the comprehensive smoking index).

Table 3 presents associations between each allergic disease and lung cancer. Taken as a whole, the ORs pointed toward a lower risk of lung cancer for each allergic disease. When restricted to those who reported using medication for their allergic disease, associations were slightly stronger; estimated ORs were generally further from the null. For asthma, the point estimate OR was 0.90, which decreased to 0.76 when excluding reports of asthma onset within 2 years of the reference age and then to 0.64 when restricting to subjects who reported using medication for their asthma. Weak negative associations were observed between eczema and lung cancer, whereas hay fever had a strong inverse association with lung cancer. Further mutual adjustment of allergic diseases in the regression models had little effect on the observed associations (data not shown).

Table 3.

History of allergic diseases and lung cancer risk in all subjects and separately for men and women, Montreal Lung Cancer Case-Control study, 1996 to 2002

All subjects

$\begin{array}{lll} & \text { Contro } \\ \text { Cases } & \text { Is } & \text { OR } \\ (\mathrm{n}=1, & (\mathrm{n}=1, & (95 \% \\ 169) & 486) & \text { Cl })^{\mathrm{a}}\end{array}$

Men

$\begin{array}{lll}\text { Case } & \text { Contr } & \\ \mathrm{S} & \text { ols } & \text { OR } \\ (\mathrm{n}=7 & (\mathrm{n}=8 & (95 \%\end{array}$

11)

646 65

\subsection{0}

(0.65

1.24)

Medica

tion

use $^{\text {b }}$

Asthma excludi

ng

cases

that occurre $\mathrm{d}<2 \mathrm{y}$ before referen ce age
$0.79 \quad 54$

(0.56

1.11)
80)

Cl)

Women

\begin{tabular}{lll}
\hline Case & Contr & \\
$\mathrm{s}$ & ols & OR \\
$(\mathrm{n}=4$ & $(\mathrm{n}=6$ & $(95 \%$ \\
$58)$ & $06)$ & $\mathrm{Cl})^{\mathrm{a}}$
\end{tabular}

\begin{tabular}{|l|l|l|l|l|}
\hline 814 & 1.00 & 395 & 532 & 1.00 \\
\hline 66 & 1.04 & 63 & 74 & 0.82 \\
& $(0.67$ & & & $(0.50$ \\
& - & & & - \\
& $1.61)$ & & & $1.34)$ \\
\hline 56 & 1.00 & 54 & 70 & 0.66 \\
& $(0.62$ & & & $(0.39$ \\
& - & & & - \\
\hline & $1.60)$ & & & $1.11)$
\end{tabular}




\begin{tabular}{|c|c|c|c|c|c|c|c|c|c|}
\hline & \multicolumn{3}{|c|}{ All subjects } & \multicolumn{3}{|l|}{ Men } & \multicolumn{3}{|c|}{ Women } \\
\hline & $\begin{array}{l}\text { Cases } \\
(\mathrm{n}=1 \\
169)\end{array}$ & $\begin{array}{l}\text { Contro } \\
\text { Is } \\
(n=1, \\
486)\end{array}$ & $\begin{array}{l}\text { OR } \\
(95 \% \\
\mathrm{Cl})^{\mathrm{a}}\end{array}$ & $\begin{array}{l}\text { Case } \\
\mathrm{s} \\
(\mathrm{n}=7 \\
11)\end{array}$ & $\begin{array}{l}\text { Contr } \\
\text { ols } \\
(n=8 \\
80)\end{array}$ & $\begin{array}{l}\text { OR } \\
(95 \% \\
\mathrm{Cl})^{\mathrm{a}}\end{array}$ & $\begin{array}{l}\text { Case } \\
\mathrm{s} \\
(\mathrm{n}=4 \\
58)\end{array}$ & $\begin{array}{l}\text { Contr } \\
\text { ols } \\
(n=6 \\
06)\end{array}$ & $\begin{array}{l}\text { OR } \\
(95 \% \\
\mathrm{Cl})^{\mathrm{a}}\end{array}$ \\
\hline Yes & 93 & 124 & $\begin{array}{l}0.76 \\
(0.54 \\
- \\
1.08)\end{array}$ & 42 & 56 & $\begin{array}{l}0.81 \\
(0.50 \\
- \\
1.34)\end{array}$ & 51 & 68 & $\begin{array}{l}0.77 \\
(0.46 \\
- \\
1.29)\end{array}$ \\
\hline $\begin{array}{l}\text { Medica } \\
\text { tion } \\
\text { use }^{\underline{b}}\end{array}$ & 77 & 115 & $\begin{array}{l}0.64 \\
(0.44 \\
- \\
0.93)\end{array}$ & 33 & 48 & $\begin{array}{l}0.71 \\
(0.41 \\
- \\
1.22)\end{array}$ & 44 & 67 & $\begin{array}{l}0.61 \\
(0.35 \\
- \\
1.05)\end{array}$ \\
\hline \multicolumn{10}{|l|}{ Eczema } \\
\hline No & 1,115 & 1,397 & 1.00 & 687 & 854 & 1.00 & 428 & 543 & 1.00 \\
\hline Yes & 54 & 89 & $\begin{array}{l}0.73 \\
(0.48 \\
- \\
1.12)\end{array}$ & 24 & 26 & $\begin{array}{l}0.77 \\
(0.41 \\
- \\
1.44)\end{array}$ & 30 & 63 & $\begin{array}{l}0.83 \\
(0.45 \\
- \\
1.53)\end{array}$ \\
\hline $\begin{array}{l}\text { Medica } \\
\text { tion } \\
\text { use }^{\complement}\end{array}$ & 30 & 61 & $\begin{array}{l}0.63 \\
(0.38 \\
- \\
1.07)\end{array}$ & 11 & 20 & $\begin{array}{l}0.45 \\
(0.20 \\
- \\
1.03)\end{array}$ & 19 & 41 & $\begin{array}{l}0.98 \\
(0.48 \\
- \\
2.01)\end{array}$ \\
\hline \multicolumn{10}{|l|}{$\begin{array}{l}\text { Hay } \\
\text { fever }\end{array}$} \\
\hline No & 1,130 & 1,354 & 1.00 & 687 & 823 & 1.00 & 443 & 531 & 1.00 \\
\hline Yes & 39 & 132 & $\begin{array}{l}0.37 \\
(0.24 \\
- \\
0.59)\end{array}$ & 24 & 57 & $\begin{array}{l}0.53 \\
(0.30 \\
- \\
0.95)\end{array}$ & 15 & 75 & $\begin{array}{l}0.23 \\
(0.10 \\
- \\
0.49)\end{array}$ \\
\hline $\begin{array}{l}\text { Medica } \\
\text { tion } \\
\text { use }^{\text {d }}\end{array}$ & 22 & 91 & $\begin{array}{l}0.33 \\
(0.19 \\
- \\
0.59)\end{array}$ & 13 & 39 & $\begin{array}{l}0.46 \\
(0.22 \\
- \\
0.98)\end{array}$ & 9 & 52 & $\begin{array}{l}0.22 \\
(0.08 \\
- \\
0.55)\end{array}$ \\
\hline \multicolumn{10}{|l|}{$\begin{array}{l}\text { Indepen } \\
\text { dent } \\
\text { and } \\
\text { joint } \\
\text { effects }{ }^{-}\end{array}$} \\
\hline $\begin{array}{l}\text { None } \\
\text { of the } \\
\text { allergic } \\
\text { disease } \\
\text { s }\end{array}$ & 967 & 1,190 & 1.00 & 612 & 750 & 1.00 & 355 & 440 & 1.00 \\
\hline $\begin{array}{l}\text { Asthm } \\
\text { a only }\end{array}$ & 81 & 77 & $\begin{array}{l}0.98 \\
(0.65 \\
- \\
1.47)\end{array}$ & 33 & 41 & $\begin{array}{l}0.81 \\
(0.46 \\
- \\
1.44)\end{array}$ & 48 & 36 & $\begin{array}{l}1.27 \\
(0.69 \\
- \\
2.34)\end{array}$ \\
\hline Eczem & 42 & 59 & 0.80 & 16 & 18 & 0.71 & 26 & 41 & 1.05 \\
\hline
\end{tabular}


a only

\begin{tabular}{l|l|}
$\begin{array}{l}\text { Hay } \\
\text { fever } \\
\text { only }\end{array}$ & \\
\hline
\end{tabular}

$\geq 2$

allergic

disease

$\mathrm{S}$

Abbreviations: $\mathrm{Cl}$, confidence interval; OR, odds ratio.

All subjects

\begin{tabular}{lll}
\hline & Contro & \\
Cases & Is & OR \\
$(n=1$, & $(n=1$, & $(95 \%$
\end{tabular}
486)

$\mathrm{Cl})^{\mathrm{a}}$

Women

\begin{tabular}{lll}
\hline Case & Contr & \\
$\mathrm{s}$ & ols & OR \\
$(\mathrm{n}=7$ & $(\mathrm{n}=8$ & $(95 \%$ \\
$11)$ & $80)$ & Cl $)^{\mathrm{a}}$
\end{tabular}

$\overline{1.31)}$

89

0.43

(0.26

0.74)

14

55

0.30

(0.15

$\overline{0.59)}$
$\mathrm{Cl})^{\mathrm{a}}$

(0.33

1.55)

\begin{tabular}{lll}
\hline Case & Contr & \\
$\mathrm{s}$ & Ols & OR \\
$(\mathrm{n}=4$ & $(\mathrm{n}=6$ & $(95 \%$ \\
$58)$ & $06)$ & $\mathrm{Cl})^{\mathrm{a}}$
\end{tabular}

(0.54

2.05)

0.35

(0.14

$\overline{0.87)}$

0.97)

$0.67 \quad 4$

$(0.27$

1.66)
0.11

(0.03

$\overline{0.39)}$

a

Models adjusted for age, sex (except in sex-specific analyses), education, respondent status, ethnocultural origin, fruit and vegetable consumption, and smoking (represented by the comprehensive smoking index).

b

Data were missing for 6 cases.

C

Data were missing for 14 cases and 2 controls.

d

Data were missing for 1 case and 2 controls.

e

Excluding asthma that occurred 2 years before the reference age.

As presented in Table 3 , when examining subjects who had only 1 of the allergic diseases, patterns of results were similar to those that did not restrict to 1 disease at a time: there was no evidence of an association with a history of asthma alone, there was a modest association with eczema alone, and there was a lower lung cancer risk in subjects reporting hay fever only compared with those with no allergic disease. Further, subjects having had at least 2 allergic diseases were at an even lower risk. The latter effect was driven largely by the strong inverse association between hay fever and lung cancer. Indeed, in those having 
at least 2 allergic diseases, 6 of 14 cases (43\%) and 42 of 55 controls (76\%) had hay fever. Although the direction of associations was very similar between men and women, ORs were further from the null for women than for men who reported a history of asthma. More pronounced inverse associations also were observed in women who reported a history of hay fever compared with men. Although the point estimates were consistently lower for women than for men, tests for interaction between sex and allergic diseases showed no different effect by sex ( $P=.68$ for asthma, $P=.92$ for eczema, $P=.14$ for hay fever).

Table 4 presents results from additional analyses of lung cancer risk according to age at onset and years since onset of each allergic disease. Most subjects indicated their allergic disease to have occurred during adulthood, at or after 20 years of age. There was no clear difference in ORs according to whether onset of the allergic disease was before or after 20 years of age. Moreover, no differences were observed according to the duration of elapsed time from allergic disease onset to the reference date, with the only exception noted earlier that the OR for the association between asthma and lung cancer changed when subjects who had reported their asthma to have occurred less than 2 years before the reference age were excluded from the analyses. Regarding eczema and hay fever and using broader intervals for years since onset, the direction of the association was essentially unchanged. However, the strength of the relation between hay fever, reported to have occurred within the previous 10 years before the reference age, and lung cancer was weakened (OR $0.52,95 \% \mathrm{Cl} 0.18-1.50$ ). Similar patterns were observed when restricting analyses to those who reported medication use for their allergic disease (data not shown).

Table 4.

Associations with lung cancer according to age at onset and years since onset of allergic diseases, Montreal Lung Cancer Case-Control study, 1996 to 2002

Asthma

\begin{tabular}{|l|}
\hline No \\
\hline Age \\
at \\
ons \\
et \\
(y)
\end{tabular}

Eczema

\begin{tabular}{|c|c|c|c|c|c|}
\hline $\begin{array}{l}\text { Cas } \\
e^{\underline{a}}\end{array}$ & $\begin{array}{l}\text { Contr } \\
\text { ols }\end{array}$ & $\begin{array}{l}\text { OR } \\
(95 \% \\
\mathrm{Cl})^{\underline{b}}\end{array}$ & $\begin{array}{l}\text { Cas } \\
\text { es }^{\underline{a}}\end{array}$ & $\begin{array}{l}\text { Contr } \\
\text { ols }\end{array}$ & $\begin{array}{l}\text { OR } \\
(95 \% \\
\mathrm{Cl})^{\underline{b}}\end{array}$ \\
\hline $\begin{array}{l}1,11 \\
5\end{array}$ & 1,397 & 1.00 & $\begin{array}{l}1,13 \\
0\end{array}$ & 1,354 & 1.00 \\
\hline
\end{tabular}

Hay fever

\begin{tabular}{lll} 
Cas & Contr & $\begin{array}{l}\text { OR } \\
(95 \%\end{array}$ \\
\hline es $^{\underline{a}}$ & ols & Cl $)^{\underline{b}}$ \\
\hline 1,04 & 1,346 & 1.00 \\
1 & &
\end{tabular}

(1)




\begin{tabular}{|c|c|c|c|c|c|c|c|c|c|c|}
\hline & \multicolumn{4}{|c|}{ Asthma } & \multicolumn{3}{|c|}{ Eczema } & \multicolumn{3}{|c|}{ Hay fever } \\
\hline & $\begin{array}{l}\text { Cas } \\
\mathrm{es}^{\mathrm{a}}\end{array}$ & $\begin{array}{l}\text { Contr } \\
\text { ols }\end{array}$ & $\begin{array}{l}\text { OR } \\
(95 \% \\
\mathrm{Cl})^{\underline{b}}\end{array}$ & & $\begin{array}{l}\text { Cas } \\
\text { es }^{\underline{a}}\end{array}$ & $\begin{array}{l}\text { Contr } \\
\text { ols }\end{array}$ & $\begin{array}{l}\text { OR } \\
(95 \% \\
\mathrm{Cl})^{\underline{b}}\end{array}$ & $\begin{array}{l}\text { Cas } \\
\mathrm{es}^{\mathrm{a}}\end{array}$ & $\begin{array}{l}\text { Contr } \\
\text { ols }\end{array}$ & $\begin{array}{l}\text { OR } \\
(95 \% \\
\mathrm{Cl})^{\underline{b}}\end{array}$ \\
\hline $0^{<2}$ & 12 & 22 & $\begin{array}{l}0.63 \\
(0.26- \\
1.53)\end{array}$ & & 17 & 30 & $\begin{array}{l}0.81 \\
(0.40- \\
1.64)\end{array}$ & 11 & 36 & $\begin{array}{l}0.38 \\
(0.17- \\
0.87)\end{array}$ \\
\hline $\begin{array}{l}\geq 2 \\
0\end{array}$ & 105 & 115 & $\begin{array}{l}0.94 \\
(0.67- \\
1.33)\end{array}$ & & 28 & 54 & $\begin{array}{l}0.65 \\
(0.37- \\
1.13)\end{array}$ & 27 & 89 & $\begin{array}{l}0.41 \\
(0.24- \\
0.70)\end{array}$ \\
\hline \multicolumn{11}{|l|}{$\begin{array}{l}\text { Yea } \\
\text { rs } \\
\text { sinc } \\
\text { e } \\
\text { ons } \\
\text { et }\end{array}$} \\
\hline$\leq 2$ & 24 & 15 & $\begin{array}{l}1.96 \\
(0.85- \\
4.50)\end{array}$ & & & & & & & \\
\hline $\begin{array}{c}>2 \\
-\leq 5\end{array}$ & 20 & 19 & $\begin{array}{l}0.96 \\
(0.43- \\
2.13)\end{array}$ & $\begin{array}{l}\text { Yea } \\
\text { rs } \\
\text { sinc } \\
\text { e } \\
\text { ons } \\
\text { et }\end{array}$ & & & & & & \\
\hline $\begin{array}{l}>5 \\
- \\
\leq 10\end{array}$ & 23 & 21 & $\begin{array}{l}1.13 \\
(0.54- \\
2.36)\end{array}$ & $\leq 10$ & 8 & 19 & $\begin{array}{l}0.50 \\
(0.19- \\
1.27)\end{array}$ & 8 & 15 & $\begin{array}{l}0.52 \\
(0.18- \\
1.50)\end{array}$ \\
\hline $0^{>1}$ & 50 & 82 & $\begin{array}{l}0.65 \\
(0.41- \\
1.01)\end{array}$ & $>10$ & 37 & 65 & $\begin{array}{l}0.78 \\
(0.47- \\
1.28)\end{array}$ & 30 & 110 & $\begin{array}{l}0.38 \\
(0.23- \\
0.63)\end{array}$ \\
\hline
\end{tabular}

Abbreviations: $\mathrm{Cl}$, confidence interval; OR, odds ratio.

a

Numbers might not add to the total shown in $\underline{\text { Table } 3}$ because of missing data ( 14 for asthma, 14 for eczema, 8 for hay fever).

b

Models adjusted for age, sex, education, respondent status, ethnocultural origin, fruit and vegetable consumption, and smoking (represented by the comprehensive smoking index).

The associations between each allergic disease and lung cancer according to smoking levels are presented in Table 5 . Slightly stronger associations were observed in subjects who were heavier smokers, but there was no evidence of an effect modification of the associations by smoking (tests for interaction: $P=$ 
.875 for asthma, $P=0.698$ for asthma excluding cases that occurred $<2$ years before the reference age, $P=.915$ for eczema, $P=.985$ for hay fever). In separate analyses focusing on current and former smokers, similar associations were observed, specifically between asthma and lung cancer (data not shown). Compared with never-smokers, no relation was found between smoking behavior (intensity and time since cessation) and asthma occurring 2 years before the reference age ( $P=.63$ for cases, $P=.24$ for controls) or between smoking behavior and hay fever ( $P=.40$ for cases, $P=.49$ for controls).

Table 5.

Associations between allergic diseases and lung cancer according to lifetime smoking levels, Montreal Lung Cancer Case-Control study, 1996 to 2002

\section{Never/lighter smokers ${ }^{\underline{a}} \quad$ Heavier smokers ${ }^{\underline{b}}$}

\begin{tabular}{|c|c|c|c|c|c|}
\hline Cases $^{\complement}$ & Controls & $\begin{array}{l}\text { OR } \\
(95 \% \mathrm{Cl})^{d}\end{array}$ & Cases $^{c}$ & Controls & $\begin{array}{l}\text { OR } \\
(95 \% \mathrm{Cl})\end{array}$ \\
\hline 132 & 824 & & 909 & 522 & \\
\hline 12 & 78 & $\begin{array}{l}1.06 \\
(0.54- \\
2.09)\end{array}$ & 116 & 62 & $\begin{array}{l}0.84 \\
(0.58- \\
1.21)\end{array}$ \\
\hline
\end{tabular}

Asthma excluding cases that occurred $<2$ y before reference age

\begin{tabular}{|c|c|c|c|c|c|c|}
\hline Yes & 8 & 66 & $\begin{array}{l}1.00 \\
(0.46- \\
2.19)\end{array}$ & 85 & 58 & $\begin{array}{l}0.70 \\
(0.47- \\
1.03)\end{array}$ \\
\hline \multicolumn{7}{|c|}{ Eczema } \\
\hline No & 136 & 848 & & 979 & 549 & \\
\hline Yes & 8 & 54 & $\begin{array}{l}0.98 \\
(0.44- \\
2.23)\end{array}$ & 46 & 35 & $\begin{array}{l}0.70 \\
(0.42- \\
1.15)\end{array}$ \\
\hline \multicolumn{7}{|c|}{ Hay fever } \\
\hline No & 138 & 813 & & 992 & 541 & \\
\hline Yes & 6 & 89 & $\begin{array}{l}0.43 \\
(0.18- \\
1.04)\end{array}$ & 33 & 43 & $\begin{array}{l}0.35 \\
(0.21- \\
0.59)\end{array}$ \\
\hline
\end{tabular}

Abbreviations: $\mathrm{Cl}$, confidence interval; OR, odds ratio.

a

Includes never-smokers and subjects belonging to quartile 1 of the comprehensive smoking index distribution among all smokers. 
Includes subjects belonging to quartiles 2 to 4 of the comprehensive smoking index distribution among all smokers.

C

Numbers might not add to the total presented in Table 3 because of missing data ( 14 for asthma, 14 for eczema, 8 for hay fever).

d

Models adjusted for age, sex, education, respondent status, ethnocultural origin, fruit and vegetable consumption, and smoking (represented by the comprehensive smoking index).

The association between a history of each allergic disease and the main histologic subtypes of lung cancer was assessed (Table 6). Adenocarcinoma was the most common cell type, accounting for $38 \%$ of cases, whereas $29 \%$ were identified as squamous cell carcinomas, $17 \%$ as small cell carcinomas, $10 \%$ as large cell carcinomas, and $6 \%$ as unspecified histologic subtypes. As expected, the distribution differed between men and women for 2 histologic subtypes: women (47\%) were more likely than men (33\%) to present with a diagnosis of adenocarcinoma, whereas squamous cell carcinomas were less frequently diagnosed in women (20\%) compared with men (35\%). The strongest associations were observed between hay fever and adenocarcinoma, between hay fever and squamous cell carcinoma, and between eczema and small cell carcinoma, although the latter 2 associations were based on a few subjects. Altogether, a tendency for a protective effect of allergic diseases was seen across all subtypes, apart from an elevated OR for the association between asthma and large cell carcinoma. In relation to a history of asthma occurrence 2 years before the reference age, the increased risk was observed mostly in women; an OR of 2.54 (95\% $\mathrm{Cl} 0.90-7.14$, based on 11 cases) was found compared with an OR of $0.42(95 \% \mathrm{Cl} 0.09-1.93$, based on 2 cases) in men. For eczema and hay fever, the numbers were too small, especially for women, to permit separate analyses by sex.

Table 6.

History of allergic diseases and lung cancer risk according to histologic subtypes, Montreal Lung Cancer Case-Control study, 1996 to 2002 


\begin{tabular}{|c|c|c|c|c|c|c|c|c|c|}
\hline \multirow[b]{2}{*}{$\begin{array}{l}\text { Allergic } \\
\text { diseas } \\
\mathrm{e}\end{array}$} & \multirow[b]{2}{*}{$\begin{array}{l}\text { Contr } \\
\text { ols }\end{array}$} & \multicolumn{2}{|c|}{$\begin{array}{l}\text { Adenocarcino } \\
\mathrm{ma}(\mathrm{n}=447)\end{array}$} & \multicolumn{2}{|c|}{$\begin{array}{l}\text { Squamous cell } \\
\text { carcinoma }(\mathrm{n}= \\
340)\end{array}$} & \multicolumn{2}{|c|}{$\begin{array}{l}\text { Small cell } \\
\text { carcinoma }(n= \\
199)\end{array}$} & \multicolumn{2}{|c|}{$\begin{array}{l}\text { Large cell } \\
\text { carcinoma }(\mathrm{n}= \\
112)\end{array}$} \\
\hline & & $\begin{array}{l}\text { Cas } \\
\text { es }\end{array}$ & $\begin{array}{l}\text { OR } \\
(95 \% \mathrm{C} \\
\text { l) }\end{array}$ & $\begin{array}{l}\text { Cas } \\
\text { es }\end{array}$ & $\begin{array}{l}\text { OR } \\
(95 \% \mathrm{C} \\
\text { l) }\end{array}$ & $\begin{array}{l}\text { Cas } \\
\text { es }\end{array}$ & $\begin{array}{l}\text { OR } \\
(95 \% \mathrm{C} \\
\text { I) }\end{array}$ & $\begin{array}{l}\text { Cas } \\
\text { es }\end{array}$ & $\begin{array}{l}\text { OR } \\
(95 \% \text { C } \\
\text { I) }\end{array}$ \\
\hline \multicolumn{10}{|l|}{$\begin{array}{l}\text { Asthm } \\
\text { a }\end{array}$} \\
\hline No & 1,346 & 403 & 1.00 & 303 & 1.00 & 178 & 1.00 & 94 & 1.00 \\
\hline Yes & 140 & 44 & $\begin{array}{l}0.75 \\
(0.49 \\
1.15)\end{array}$ & 37 & $\begin{array}{l}0.89 \\
(0.56- \\
1.41)\end{array}$ & 21 & $\begin{array}{l}0.82 \\
(0.45- \\
1.48)\end{array}$ & 18 & $\begin{array}{l}1.74 \\
(0.91- \\
3.31)\end{array}$ \\
\hline \multicolumn{10}{|l|}{$\begin{array}{l}\text { Asthm } \\
\text { a } \\
\text { excludi } \\
\text { ng } \\
\text { cases } \\
\text { that } \\
\text { occurre } \\
d<2 \text { y } \\
\text { before } \\
\text { referen }^{2} \text { ce age }^{\text {b }}\end{array}$} \\
\hline Yes & 124 & 35 & $\begin{array}{l}0.68 \\
(0.43- \\
1.08)\end{array}$ & 27 & $\begin{array}{l}0.73 \\
(0.44- \\
1.24)\end{array}$ & 12 & $\begin{array}{l}0.61 \\
(0.30- \\
1.24)\end{array}$ & 13 & $\begin{array}{l}1.30 \\
(0.63- \\
2.69)\end{array}$ \\
\hline \multicolumn{10}{|l|}{$\begin{array}{l}\text { Eczem } \\
\mathrm{a}\end{array}$} \\
\hline No & 1,397 & 419 & 1.00 & 326 & 1.00 & 195 & 1.00 & 108 & 1.00 \\
\hline Yes & 89 & 28 & $\begin{array}{l}0.88 \\
(0.53- \\
1.47)\end{array}$ & 14 & $\begin{array}{l}0.66 \\
(0.34- \\
1.28)\end{array}$ & 4 & $\begin{array}{l}0.31 \\
(0.10- \\
0.92)\end{array}$ & 4 & $\begin{array}{l}0.52 \\
(0.16- \\
1.69)\end{array}$ \\
\hline \multicolumn{10}{|l|}{$\begin{array}{l}\text { Hay } \\
\text { fever }\end{array}$} \\
\hline No & 1,354 & 429 & 1.00 & 335 & 1.00 & 190 & 1.00 & 107 & 1.00 \\
\hline Yes & 132 & 18 & $\begin{array}{l}0.42 \\
(0.23- \\
0.74)\end{array}$ & 5 & $\begin{array}{l}0.18 \\
(0.07- \\
0.47)\end{array}$ & 9 & $\begin{array}{l}0.43 \\
(0.18- \\
1.00)\end{array}$ & 5 & $\begin{array}{l}0.63 \\
(0.24- \\
1.69)\end{array}$ \\
\hline
\end{tabular}

Abbreviations: $\mathrm{Cl}$, confidence interval; OR, odds ratio.

a

Models adjusted for age, sex, proxy, education, ethnocultural origin, fruit and vegetable consumption, and smoking (represented by the comprehensive smoking index).

b

Analyses based on 438 adenocarcinoma, 330 squamous cell carcinoma, 190 small cell carcinoma, and 107 large cell carcinoma cases. 


\section{Discussion}

One of the primary motivations for this study was to contrast the relations between lung cancer and each of 3 common allergic diseases in the same population using the same methodology. The risk estimates for all allergic diseases tended to point toward an inverse relation with lung cancer, which was weaker for asthma, of moderate strength for eczema, and strongest for hay fever. Robust associations generally were observed, irrespective of whether analyses were restricted to subjects reporting having had used medication for their allergic disease. Moreover, the ORs of lung cancer did not vary substantially according to age at onset and latency periods or by smoking levels.

Numerous qualitative and quantitative reviews have inferred an elevated lung cancer risk associated with a history of asthma. [1] [2] [3] [4] [5] ${ }^{\text {and }}[6]$ Most recently, a meta-analysis based on 52 studies suggested an increased risk of lung cancer in subjects with asthma (relative risk 1.28, 95\% $\mathrm{Cl} 1.16-1.41$ ), but with a high degree of heterogeneity as indicated by the interstudy variability of $73 \% .^{-6}$ Heterogeneity was attributed to several sources, including histology, latency, and asthma ascertainment methods. Based on findings of no association when considering latency longer than 10 years after asthma diagnosis (relative risk $0.98,95 \% \mathrm{Cl} 0.66-1.44$, based on 10 studies) and a weaker association in never-smokers (relative risk $1.20,95 \% \mathrm{Cl} 0.81-1.76$, based on 5 studies), the investigators concluded that this provided evidence against a direct causal association between asthma and lung cancer risk. In the present study, the ORs ranged from near null to quite protective as the definition of asthma was tightened. One possible reason for observing a different direction in the association between asthma and lung cancer in the present study compared with other studies could be better confounding control, especially for smoking, because analyses were stratified and adjusted by the CSI rather than simply by smoking status, as in previous studies.

There have been fewer studies on the relation between eczema and lung cancer. One study found no relation between eczema and lung cancer (OR 1.00, 95\% Cl $0.4-2.6$ ) in 196 cases and 4,271 controls..$^{13}$ In the present study, a protective effect of eczema against lung cancer was found, consistent with 2 previous studies. [8] ${ }^{\text {and }}[9]$ The first was a large case-control study reporting a strong protective effect (OR $0.61,95 \% \mathrm{Cl} 0.5-0.8$ ) between a history of eczema and lung cancer; the decreased risk was observed across all histologic 
subtypes.. Conducted by the authors' group in Montreal, the second study showed a strong inverse relation (OR $0.34,95 \% \mathrm{Cl} 0.2-0.7$ ) between a history of eczema and lung cancer in men.- Only 1 of the prior studies stratified by interval from age at onset of eczema to the reference age ${ }^{9}$; the results were unchanged, similar to the present observations.

The present finding of a protective effect of hay fever on lung cancer is in accord with most previous reports, [10] [11]' [12] [13]' [14] [15] ${ }^{\text {and }}[16]$ but not all.[36] ${ }^{\text {and }}[37]$ Of the latter, 1 was a cohort study in a population of Seventh-Day Adventists that included 62 lung cancer cases,,$\frac{36}{}$ and the second study was conducted in 98 women with small cell lung cancer. ${ }^{37}$ Similar to the present findings, associations between hay fever and lung cancer remained unchanged in previous studies when considering several latency exclusions, whether up to 10 years ${ }^{15}$ or 20 years. ${ }^{16}$ No previous study on hay fever and lung cancer risk has provided stratified analyses by histologic subtypes.

\section{Methodologic Considerations}

Response rates for cases and controls were relatively high, which lessens concerns regarding nonresponse bias affecting observed associations. It seems unlikely that there was a selective participation of subjects with allergy for 2 reasons. First, when cases and controls were initially informed and invited to take part in the original study, there was no mention of a research focus on allergy. Second, a history of allergies is not commonly thought to have an effect on lung cancer risk, and thus subjects would not select themselves into the study based on their beliefs of such a possible association.

Information bias is unlikely. Given the absence of public beliefs in an association between allergies and lung cancer, interviewers likely applied identical means of questioning cases and controls on the topic of allergic diseases. Because cases have a particular interest and motivation to seek explanations for their cancers, they might over-report exposures compared with controls. In the present situation, cases reported fewer allergic diseases than controls, with or without medication use, which would go in the opposite direction of such a bias.

There may be misclassification of exposure history resulting from the use of selfreported allergic diseases. Also, the questions were not formulated to collect information on physician-diagnosed allergic diseases. However, validity of selfreported asthma, eczema, and hay fever against clinical diagnosis has been 
shown to be relatively high.[38] [39] [40] ${ }^{\text {and }}[41]$ Most medications reported for asthma control were prescription based, suggesting that self-reported asthma was primarily physician diagnosed. This may not be the case for the other 2 allergic diseases because reported medications were a combination of prescriptions, over-the-counter drugs, and unspecified drugs. One would probably expect nondifferential misclassification errors to have occurred more for eczema and hay fever, but with resulting ORs closer to the null. All previous studies relied on self-reports to define eczema and hay fever. [8]' [9]' [10] [11]' [12]' [13]' [14] [15]' [16]' [22]' [36]' [37] and [42] For asthma and according to a most recent meta-analysis based on 52 studies that assessed the association between asthma and lung cancer, only a few relied on physician diagnoses (based on health services databases) [43] [44] [45] ${ }^{\text {and }}$ [46] and hospitalization (based on International Classification of Diseases codes) [47] [48] [49] ${ }^{\text {and }}$ [50] to define asthma status. Of particular relevance in the present study, the prevalence of self-reported allergic diseases observed compared well with what would be expected in this study population. $\frac{51}{1}$

One feature of the present study that could have led to differential information quality between cases and controls is the large number of proxy respondents. Excluding proxy answers from the analyses had no appreciable impact on results. The ORs were $0.81(95 \% \mathrm{Cl} 0.56-1.18)$ for a history of asthma occurrence 2 years before the reference age, $0.76(95 \% \mathrm{Cl} 0.49-1.20)$ for eczema, and $0.36(95 \% \mathrm{Cl} 0.22-0.60)$ for hay fever, similar to risk estimates obtained in the entire sample.

Potential reverse causation was addressed by looking at the temporal relation between age at diagnosis of allergic diseases and reference age. No sign of this bias was detected for eczema and hay fever. Asthma reported to have occurred 2 years before the reference age might have been confused as an early clinical manifestation of lung cancer. Nevertheless, reverse causality appears unlikely because observed associations were seen over a long latency period and, if present, would have resulted in inflated OR estimates above 1.0, which is not what was observed.

The potential for confounding was assessed for a wide range of data on important risk factors for lung cancer, in particular the possible confounding effect of smoking. The stratified analysis of associations between allergic diseases and lung cancer showed no differences by smoking levels. Among the particular 
strengths of this study is the availability of extensive information on multiple covariates other than smoking, the population-based study design, and consideration of incident and histologically confirmed lung cancer cases.

A consistent risk pattern emerged across the 3 allergic diseases, but one that seemed to vary in strength depending on the disease. When considering occurrence and associated medication use for each allergic disease, a clearer pattern appeared and the inverse associations became more pronounced. This might reflect a shared underlying mechanism by which a history of allergic diseases is associated with lung cancer, specifically that of the immune surveillance hypothesis.

\section{Acknowledgment}

The authors thank Dr. Florence Conus for conducting the preliminary analyses for this project. 